\title{
PENGEMBANGAN LEMBAR KERJA SISWA BERBASIS KONTEKSTUAL PADA MATERI MENULIS TEKS PERSUASI KELAS VIII SMP AR-RISALAH LUBUKLINGGAU
}

\author{
Rika Saputri ${ }^{1}$, Satinem $^{2}$, Sri Murti ${ }^{3}$ \\ ${ }^{1,2,3}$ Program Studi Pendidikan Bahasa dan Sastra Indonesia, STKIP PGRI Lubuklinggau \\ JIn. Mayor Toha Kelurahan Air Kuti, Kota Lubuklinggau, Indonesia \\ Email: rechasaputri@gmail.com ${ }^{1}$, satinemyohana@gmail.com ${ }^{2}$, srimurti05@gmail.com ${ }^{3}$
}

\begin{abstract}
Abstrak
Lembar kerja siswa (LKS) khususnya pada materi menulis teks persuasi yang digunakan guru masih berorientasi pada teks sehingga siswa kesulitan memahami materi secara kontekstual. Untuk itu, penelitian ini bertujuan untuk mengembangkan LKS menulis teks persuasi berbasis kontekstual siswa Kelas VIII SMP Ar-Risalah Lubuklinggau. Penelitian ini merupakan jenis penelitian Research and Development (R\&D) dengan menggunakan model Dick \& Carey. Teknik pengumpulan data menggunakan teknik wawancara, kuesioner, dan tes. Teknik analisis data untuk uji efektivitas menggunakan SPSS versi 20. Hasil penelitian menunjukkan bahwa LKS menulis teks persuasi berbasis kontekstual Siswa Kelas VIII SMP Ar-Risalah Lubuklinggau yang dikembangkan valid, praktis, dan efektif sehingga layak digunakan oleh guru bahasa Indonesia sebagai salah satu bahan ajar untuk mencapai tujuan pembelajaran menulis teks persuasi. Kemudian, hasil uji efektivitas produk menunjukkan bahwa penggunaan LKS menulis teks persuasi berbasis kontekstual mampu meningkatkan kemampuan menulis persuasi siswa.
\end{abstract}

Keywords: pengembangan, lembar kerja siswa, menulis teks persuasi, berbasis kontekstual

\section{DEVELOPMENT OF CONTEXTUAL-BASED STUDENT WORKSHEETS ON WRITING MATERIAL FOR PERSUASIVE TEXT CLASS VIII SMP AR-RISALAH LUBUKLINGGAU}

\begin{abstract}
Student worksheets (LKS) especially in writing persuasion text material used by teachers are still oriented to the text so students have difficulty understanding the material contextually. For this reason, this study aims to develop worksheets for writing contextual persuasion texts based on students of Class VIII at SMP Ar-Risalah Lubuklinggau. This research is a type of Research and Development (R\&D) research using the Dick \& Carey model. Data collection techniques using interview techniques, questionnaires, and tests. Data analysis techniques for effectiveness testing using SPSS version 20. The results of the study show that LKS writes contextual persuasion text based on Students of Class VIII at SMP Ar-Risalah Lubuklinggau which are developed valid, practical, and effective so that it is appropriate to be used by Indonesian language teachers as one of the teaching materials to achieve the objectives learning to write persuasive texts. Then, the results of the product effectiveness test showed that the use of LKS writing contextual persuasion text writing was able to improve students' persuasion writing skills.
\end{abstract}

Keywords: development, student worksheets, writing persuasive texts, contextual based 


\section{A. Pendahuluan}

Tujuan kegiatan pembelajaran bahasa Indonesia yaitu diarahkan pada pencapaian kompetensi dasar di bidang bahasa dan sastra, kemudian dapat memberikan arah terhadap semua kegiatan dan bahan yang akan disajikan (Sukmadinata, 2012:105). Pendidikan sekolah menengah pertama (SMP) pada tahun ajaran 2019/2020 di dalam silabus bahasa Indonesia terdapat beberapa kompetensi dasar yang harus dipelajari, salah satunya pada KD 4.14 yaitu menyajikan teks persuasi (saran, ajakan, arahan, dan pertimbangan) secara tulis dan lisan dengan memperhatikan struktur, kebahasaan, atau aspek lisan.

Teks persuasi merupakan teks yang berisikan ajakan atau bujukan yang terdapat pernyataan-pernyataan sehingga mendorong sesorang untuk mengikuti harapan atau keinginan-keinginan penulis (Astuti, 2019:23; Abdullah, 2019:2-3; Noermanzah, 2017:222-223). Sedangkan menurut Hidayati dkk. (2019:86) dan Awalludin (2018:159), teks persuasi merupakan salah satu dari hasil keterampilan menulis yang bersifat mempengaruhi pembaca dan biasanya terdapat pada iklan. Dapat disimpulkan bahwa teks persuasi merupakan teks yang dapat mempengaruhi dan membujuk pembaca untuk mengikuti pesan dalam teks yang dibacanya. Diketahui bahwa di SMP Ar-Risalah Lubuklinggau menggunakan Kurikulum 2013. Kurikulum 2013 mengarah pada siswa untuk lebih aktif dan kreatif salah satunya dengan menggunakan bahan ajar tambahan yang lebih fokus pada materi yang diajarkan yaitu materi menulis teks persuasi. Bahan ajar yang selama ini digunakan hanya melihat kemampuan siswa secara umum tidak melihat kemampuan siswa dari sisi yang lain, ditambah lagi dengan lembar kerja siswa pada materi menulis teks persuasi belum ada. Dengan demikian, banyak siswa yang kesulitan untuk belajar mengenai menulis teks persuasi, sehingga prestasi belajarnya cenderung rendah. Keterampilan menulis merupakan salah satu keterampilan bahasa menurut Amrolani dkk. (2014:1-2) \& Karto (2019:2718) sebagai kemampuan sesorang dalam menuangkan gagasanya melalui media tulisan yang bersifat produktif sehingga dibutuhkan langkah-langkah yang sistematis dalam membangkitkan semangat siswa. 
Untuk mengatasi permasalahan yang dihadapi guru dan siswa perlu adanya bahan ajar tambahan seperti halnya lembar kerja siswa (LKS) yang inovatif dan kreatif (Noermanzah, 2015:277). Lembar kerja siswa merupakan lembaran-lembaran kerja siswa yang berupa latihan atau tugas yang harus dikerjakan siswa. Hal ini sejalan dengan pendapat Daryanto \& Dwicahyono (2014:175) yang menyatakan lembar kerja siswa adalah lembaran-lembaran yang berisi tugas yang harus dikerjakan oleh siswa yang di dalamnya berisikan petunjuk atau langkah-langkah dalam mengerjakan tugas. Selanjutnya, menurut Fannie \& Rohati (2014:98), LKS merupakan stimulus atau bimbingan guru dalam proses pembelajaran yang dipaparkan secara tertulis, kemudian dalam penulisannya perlu memperhatikan kriteria sebagai media untuk dapat menarik perhatian siswa. Fungsi lembar kerja siswa yaitu lebih ditujukan untuk memandu siswa ketika dalam proses pembelajaran untuk dapat menemukan konsep materi yang dipelajari (Agustin, 2019:37-38). Dengan demikian, keberadaan bahan ajar sangat membantu dalam kegiatan belajar mengajar, agar materi akan dapat tersampaikan dengan baik kepada siswa (Nugroho dkk., 2019:2).

Proses pembelajaran menggunakan LKS agar sesuai tujuan dan harapan yang diinginkan dalam menulis teks persuasi perlunya suatu pendekatan salah satunya pendekatan kontekstual. Kontekstual itu sendiri sesuatu yang berkaitan antara materi dengan lingkungan atau dunia sekitarnya yang pernah dilihat atau pernah dirasakan (Puspita \& Purwo, 2019:2). Menurut Haikal dkk. (2018:1-2) pembelajaran kontekstual yaitu pengetahuan dan keterampilan siswa yang diperolehnya dengan mengaitkan ketika belajar siswa akan turut langsung dalam pengalaman belajar yang akan membuat kegiatan belajar lebih bermakna.

Bahan ajar menulis teks persuasi baru sebatas pada penggunaan video seperti yang telah dilakukan oleh Bomasati (2019). Hasil penelitian yang dilakukannya menunjukkan bahwa produk LKPD layak digunakan dalam pembelajaran menulis teks persuasif untuk siswa SMP kelas VIII. Hal ini dibuktikan dari penelitian yang menunjukkan bahwa: 1) telah berhasil dikembangkan produk bahan ajar berupa LKPD menulis teks persuasif 
menggunakan video untuk siswa SMP kelas VIII, 2) hasil penelitian kelayakan bahan ajar secara keseluruhan dinyatakan "Sangat Layak" oleh ahli materi, ahli media, dan ahli praktisi.

Rancangan pembuatan lembar kerja siswa berbasis kontekstual yang dilakukan oleh peneliti yaitu dikaitan dengan konteks lingkungan ataupun situasi siswa dan juga peneliti melengkapi materi dan menambah gambar yang sesuai dengan konsep pada materi, sehingga menjadi sumber belajar yang menarik, dengan demikian diharapkan mampu sebagai penunjang dalam keberhasilan pembelajaran menulis teks persuasi siswa kelas VIII SMP Ar-Risalah Lubuklinggau.

\section{B. Metode Penelitian}

Penelitian ini merupakan penelitian pengembangan (Research \& Development) yang merupakan suatu metode dengan langkah-langkah yang sudah ditentukan untuk mengembangkan suatu produk dan juga dapat diuji keefektifannya. Produk yang dikembangkan dalam penelitian ini adalah lembar kerja siswa menulis teks persuasi berbasis kontekstual. Penelitian ini dilaksanakan di SMP Ar-Risalah Lubuklinggau pada siswa kelas VIII tahun ajaran 2019/2020.

Desain penelitian yang digunakan dalam penelitian ini menggunakan model Dick \& Carey yang mengacu pada (Tegeh, dkk 2014:31), bahwa prosedur ini umumnya dilakukan dengan sepuluh langkah pelaksanaan namun dalam penelitian ini hanya sampai pada tahap ke 8 yaitu: a) analisis kebutuhan dan tujuan, b) analisis pembelajaran, c) analisis pembelajar dan konteks, d) menuliskan tujuan unjuk kerja, e) mengembangkan instrumen, f) mengembangkan strategi pembelajaran, g) mengembangkan dan memilih bahan pembelajaran, $h$ ) melakukan evaluasi formaif, i) merevisi pembelajaran, dan j) merancang dan melaksanakan evaluasi sumatif. Namun, dalam penerapan langkah-langkah pengembangan dapat disesuaikan dengan kebutuhan peneliti.

Analisis data melalui validasi produk diuji oleh pakar atau orang ahli di bidangnya validator tersebut diantaranya (1) Taupik Hidayat, S.Pd. (ahli materi) (2) Dr. Rusmana Dewi, M.Pd. (ahli kebahasaan) (3) Dr. Dodik Mulyono, M.Pd. 
(ahli desain). Setelah dilakukannya validasi, langkah selanjutnya mengevaluasi dan merevisi produk. Setelah dilakukannya revisi kemudian diimplementasikan melalui evaluasi formatif sebagai proses pengumpulan data yang dilakukan selama produk pengembangan, sehingga dapat memperbaiki keadaan produk sebelumnya mendapatkan suatu produk akhir. Dengan demikian, proses evaluasi formatif dilakukan melalui tiga langkah: a) uji coba portotipe bahan secara perorangan (one-to-one triying out). Uji coba ini merupakan uji coba yang digunakan untuk mendapatkan masukan awal. b) Uji coba kelompok kecil (small group tryout) melibatkan subjek 5-8 orang hasil uji coba ini digunakan untuk melanjutkan revisi produk, bahan, material atau desain sesuai dengan masukan yang diberikan oleh kelompok sasaran tersebut.

c) Uji coba lapangan (field tryout), melibatkan subjek dalam kelas yang lebih besar 15-30 subjek. Hasil uji coba lapangan ini digunakan untuk melakukan revisi produk, bahan, material atau rancangan final. Selama uji coba ini, peneliti tidak hanya menggunakan data kuantitatif, namun juga menggunakan data kualitatif yang diperoleh melalui observasi dan wawancara. Teknik pengumpulan data dengan menggunakan instrumen, yaitu instrumen berbentuk wawancara, kuesioner atau angket dan tes. Teknik analisis data untuk uji efektivitas LKS menggunakan SPSS versi 20.

\section{Hasil Penelitian dan Pembahasan}

\section{Hasil Penelitian}

Hasil penelitian terhadap pengembangan lembar kerja siswa menulis teks persuasi berbasis kontekstual pada tahap evaluasi ahli dilakukan oleh (1) Dr. Dodik Mulyono, M.Pd. (ahli desain). Berdasarkan perhitungan validasi ahli desain dapat disimpulkan bahwa kelayakan lembar kerja siswa masuk ke dalam kategori baik dengan persentase 77,08\%. (2) Dr. Rusmana Dewi, M.Pd. (ahli kebahasaan), berdasarkan perhitungan validasi ahli kebahasaan dapat disimpulkan bahwa kelayakan isi materi masuk kedalam kategori baik dengan persentase $75 \%$. (3) Taupik Hidayat S.Pd. (ahli materi), berdasarkan perhitungan validasi ahli materi 
dapat disimpulkan bahwa kelayakan isi materi masuk kedalam kategori sangat baik dengan persentase $87,5 \%$. Dengan demikian, dapat disimpulkan secara keseluruhan evaluasi ahli dalam kategori baik, dengan persentase 79,86\%.

Hasil data one to one lembar kerja siswa menulis teks persuasi diperoleh dari beberapa indikator yaitu: a) penampilan keseluruhan LKS, b) keterbacaan isi materi, c) kesesuaian gambar, d) kemudahan dan tingkat kesulitan lembar kerja siswa menulis teks persuasi mudah dipahami dan penampilan secara keseluruhan bagus/menarik. Hal ini dibuktikan dengan peneliti memberi pertanyaan kepada siswa dan antusias siswa dalam penggunaan LKS. Peneliti menggunakan bahasa yang sederhana sehingga mudah untuk dipahami, dan materi yang disajikan lengkap. Dapat disimpulkan bahwa bahan ajar berupa LKS menulis teks persuasi berbasis kontekstual dapat digunakan pada saat pembelajaran menulis teks persuasi. Pelaksanaan uji coba kelompok kecil yang diperoleh dari angket yang diberikan, bahwa respons siswa terhadap lembar kerja siswa menulis teks persuasi berbasis kontekstual dengan kategori sangat setuju dengan persentase $84,57 \%$.

Tahap terakhir dalam pengembangan LKS yaitu uji coba lapangan. Uji coba dilakukan pada kelas VIII Ibnu Kholdun SMP Ar-Risalah Lubuklinggau dengan jumlah 33 siswa. Pada kegiatan uji coba ini untuk mendapatkan informasi secara menyeluruh tentang kualitas produk LKS. Berdasarkan hasil tes dengan menggunakan LKS menulis teks persuasi dapat dikatakan efektif apabila mendapatkan nilai $>76$. Berdasarkan uji coba kelompok besar yang terdiri dari 33 siswa dapat disimpulkan bahwa respons siswa dikategorikan sangat baik dengan persentase $92,12 \%$.

\section{Pembahasan}

Lembar kerja siswa (LKS) menulis teks persuasi berbasis kontekstual siswa Kelas VIII SMP Ar-Risalah Lubuklinggau yang dikembangkan valid, praktis, dan efektif sehingga layak digunakan oleh guru bahasa Indonesia sebagai salah satu bahan ajar untuk mencapai tujuan pembelajaran menulis teks persuasi. Kemudian, hasil uji efektivitas produk menunjukkan bahwa penggunaan LKS 
menulis teks persuasi berbasis kontekstual mampu meningkatkan kemampuan menulis persuasi siswa. Hal ini sesuai dengan pendapat Puspita \& Purwo, (2019:2) dan Haikal dkk. (2018:1-2) bahwa pendekatan kontekstual mampu memberikan pemahaman awal pada siswa tentang materi yang dipelajari sehingga siswa termotivasi dan mampu melaksanakan langkah-langkah yang ia pelajari, dalam hal ini langkah-langkah menulis teks persuasi.

Lembar kerja siswa pada desain cover setelah divalidasi tampilan tidak terlalu jauh berbeda karena hanya diperbaiki dengan menambahkan keterangan pada LKS yang dibuat yaitu berbasis kontekstual. Gambar yang ditampilkan pada LKS berkaitan dengan materi menulis teks persuasi serta warna tidak terlalu mencolok. Kemudian spasi, huruf, dan tanda selalu diperhatikan oleh penulis. LKS dicetak dengan menggunakan kertas A4 dan tidak terlalu tebal hanya 17 lembar dan dijilid dengan rapi.

Evaluasi kevalidan terhadap penelitian pengembangan lembar kerja siswa menulis teks persuasi berbasis kontekstual siswa kelas VIII SMP Ar-Risalah Lubuklinggau dilakukan dengan memberikan angket penilaian kepada validator ahli. Evaluasi ini dilakukan oleh tiga ahli diantaranya ahli desain Dr. Dodik Mulyono, M.Pd., ahli kebahasaan Dr. Rusmana Dewi, M.Pd., dan ahli materi Taupik Hidayat, S.Pd. hasil angket dari para ahli dapat dijadikan acuan untuk valid atau tidak terhadap lembar kerja siswa yang dikembangkan oleh peneliti.

Berdasarkan analisis hasil angket yang telah diberikan oleh ahli desain, lembar kerja siswa menulis teks persuasi berbasis kontekstual dikategorikan baik dengan persentase $77,08 \%$. Dengan demikian, lembar kerja siswa menulis teks persuasi berbasis kontekstual telah valid dan dapat digunakan. Selanjutnya, hasil perhitungan dan analisis angket yang diberikan kepada ahli kebahasaan lembar kerja siswa menulis teks persuasi berbasis kontekstual dengan persentase $75 \%$ kategori baik. Penulis juga tidak lupa merevisi sesuai kritik dan saran yang telah diberikan oleh ahli kebahasaan. Analisis hasil angket yang diberikan kepada ahli materi mendaptkan persentase $87,5 \%$ dengan kategori sangat baik. Hasil secara keseluruhan analisis angket yang diberikan oleh para ahli mendapatkan 
persentase $79,86 \%$ dengan kategori baik artinya lembar kerja siswa menulis teks persuasi berbasis kontekstual telah layak digunakan.

Lembar kerja siswa menulis teks persuasi berbasis kontekstual dalam uji coba kepraktisan melalui uji portotipe atau one to one. Pada uji coba ini dilakukan kepada 3 orang siswa secara acak dengan menggunakan wawancara terkait dengan kepraktisan lembar kerja siswa yang penulis kembangkan. Hasil yang diperoleh dari wawancara terhadap 3 orang siswa mendapat respons positif. Kemudian, penulis juga menggunakan evaluasi kelompok kecil yang berupa angket dengan jumlah 10 butir pertanyaan, pada evaluasi kelompok kecil ini angket yang diberikan hanya kepada 6 orang siswa. Selanjutnya, hasil analisis angket yang yang telah diberikan pada evaluasi kelompok kecil mendapatkan persentase $84,57 \%$ dengan kategori sangat positif. Artinya lembar kerja siswa menulis teks persuasi berbasis kontekstual sudah praktis dan dapat digunakan.

Uji coba lembar kerja siswa menulis teks persuasi berbasis kontekstual dikatakan tuntas apabila mencapai KKM yang telah ditetapkan yaitu 76. Setelah 33 orang siswa kelas VIII Ibnu Kholdun SMP Ar-Risalah Lubuklinggau mengikuti kegitan post-test yang dilakukan oleh peneliti 30 siswa dinyatakan tuntas karena telah mencapai KKM, sedangkan 3 orang siswa belum tuntas karena belum mencapai KKM. Hasil kegiatan post-test tersebut diketahui nilai tertinggi mencapai 90 dan nilai terendah mencapai 65 . Kevalidan instrumen dilihat berdasarkan nilai pre-test dan post-test, hasil validasi instrumen diperleh 1,00 dikategorikan sangat tinggi. Setelah diketahui kevalidan instrumen selanjutnya menentukan kesignifikan hubungan lembar kerja siswa menulis teks persuasi berbasis kontekstual kelas VIII SMP Ar-Risalah Lubuklinggau menggunakan SPSS versi 20.

Berdasarkan hasil perhitungan diketahui $t_{\text {hitung }}$ sebesar 88,502, selanjutnya mencari $t_{\text {tabel }}$ dengan tabel nilai dalam distribusi t. Taraf signifikan $\alpha=0,05$ dengan derajat kebebasan $(\mathrm{dk}=\mathrm{df}) 32$, maka diketahui $\mathrm{t}_{\text {tabel }}=1,697$. Berdasarkan kriteria pengujiannya jika $t_{\text {hitung }}>\mathrm{t}_{\text {tabel }}$ berarti valid, sebaliknya jika $t_{\text {hitung }} \leq \mathrm{t}_{\text {tabel }}$ berarti tidak valid. Hasil perhitungan menunjukan bahwa $t_{\text {hitung }}>t_{\text {tabel }}(88,502>1,697)$ dengan nilai sig sebesar 0,000 , artinya lembar kerja siswa menulis teks persuasi berbasis 
kontekstual terdapat hubungan yang positif terhadap hasil belajar siswa kelas VIII SMP Ar-Risalah Lubuklinggau.

Langkah berikutnya mencari nilai reliabilitas instrumen menggunakan rumus alpha. Sebelum menggunakan rumus alpha terlebih dahulu mengetahui varians butir dan varians total. Berdasarkan perhitungan diketahui varians butir 15,36 dan untuk hasil varian total 28,79. Hasil dari perhitungan reliabilitas instrumen lembar kerja siswa menulis teks persuasi berbasis kontekstual dikategorikan sedang nilai 0,54.

Langkah terakhir menghitung efektif tidaknya lembar kerja siswa menulis teks persuasi berbasis kontekstual dengan menggunakan paired sample uji-t dengan SPSS versi 20. Diketahui mean atau nilai rata-rata sebelum 44,75 sedangkan sesudah mendapat mean 82,67 dengan jumlah 33 siswa yang dijadikan sampel. Nilai rata-rata hasil belajar sebelum dan sesudah yang telah diketahui maka langkah selanjutnya paired sample correlations adalah rumus yang digunakan untuk mencari nilai korelasi nilai rata-rata. Pada tabel paired sample correlations diperoleh sig 0,752 lebih besar dari alpha value 0,05. Berdasarkan pengambilan keputusan dari uji correlations menunjukkan ada hubungan yang signifikan antara data nilai rata-rata sesudah dan sebelum menggunakan lembar kerja siswa menulis teks persuasi berbasis kontekstual. Hasil output paired sample tes nilai mean atau nilai rata-rata sebelum dan sesudah sebesar 37,90 dengan sig (2-tailed) sebesar 0,000 (lebih kecil dari alpha value).

Berdasarkan hasil output paired sample tes maka lembar kerja siswa menulis teks persuasi berbasis kontekstual terdapat perbedaan yang signifikan antara sebelum dan sesudah menggunakan. Oleh karena itu, dapat dinyatakan bahwa lembar kerja siswa menulis teks persuasi berbasis kontekstual sudah valid, praktis dan efektif sehingga layak digunakan oleh guru bahasa Indonesia. 


\section{Simpulan}

Berdasarkan hasil penelitian dan pembahasan dapat disimpulkan lembar kerja siswa (LKS) menulis teks persuasi berbasis kontekstual siswa Kelas VIII SMP Ar-Risalah Lubuklinggau yang dikembangkan valid, praktis, dan efektif sehingga layak digunakan oleh guru bahasa Indonesia sebagai salah satu bahan ajar untuk mencapai tujuan pembelajaran menulis teks persuasi. Lembar kerja siswa menulis teks persuasi yang dikembangkan oleh peneliti berbentuk bahan ajar dengan mengaitkan kehidupan sehari-hari atau sering disebut dengan kontekstual dan materi yang disajikan secara singkat dan terdapat contoh, latihan, serta tugas akhir.

Berdasarkan hasil validasi ahli, kevalidan dilakukan dengan pengisian angket yang diberikan kepada validator ahli. Evaluasi ini dilakukan oleh tiga ahli antara lain ahli desain, bahasa, dan materi dengan hasil secara keselurahan yang telah didapatkan dengan persentase $79,86 \%$ dengan kategori baik. LKS menulis teks persuasi berbasis kontektual dapat dikatakan valid. Kepraktisan lembar kerja siswa menulis teks persuasi dilakukan dengan uji portotipe atau one to one dengan hasil yang diperoleh dari wawancara terhadap 3 orang siswa mendapat respons positif. Kemudian, penulis juga menggunakan evaluasi kelompok kecil hasil analisis angket mendapatkan presentase $84,5 \%$ dengan kategori sangat positif. Kefektifan LKS menulis teks persuasi berbasis kontekstual dilakukan dengan kegitan post-test dan post-tes dengan hasil post-test yang dilakukan oleh peneliti 30 siswa dinyatakan tuntas karena telah mencapai KKM, sedangkan 3 orang siswa belum tuntas karena belum mencapai KKM. Hasil kegiatan post-test tersebut diketahui nilai tertinggi mencapai 90 dan nilai terendah mencapai 65 . Artinya lembar kerja siswa menulis teks persuasi berbasis kontekstual terdapat hubungan yang positif terhadap hasil belajar siswa kelas VIII SMP Ar-Risalah Lubuklinggau. 


\section{Daftar Pustaka}

Abdullah, N. (2019). Meningkatkan Kemampuan Menulis Paragraf Persuasif melalui Pola Latihan Berjenjang. Mabasan, 6(1), 1-2. doi:10.26499/mab.v6i1.217

Agustin, I. (2019). Pengembangan Lembar Kerja Siswa (LKS) untuk Meningkatkan Kemampuan Menulis Siswa Tuna Rungu di SDN Inklusi. ELSE (Elementary School Education Journal) : Jurnal Pendidikan dan Pembelajaran Sekolah Dasar, 3(1), 37-38. doi:10.30651/else.v3i1.2460

Amrolani, A., Muslihah, N. N., \& Noermanzah, N. (2014). Peningkatan Kemampuan Menulis Karangan Deskripsi melalui Teknik Imajinasi Siswa Kelas IV SD Negeri 51 Lubuklinggau. Jurnal Perspektif Pendidikan, 8(1), $1-2$.

Astuti, M. T. (2019). Yuk, Ungkap Idemu melalui Teks Persuasi Hingga Teks Tanggapan. Depok: PT. Duta.

Awalludin, A. (2018). Efektivitas Model Decision Making dalam Pembelajaran Menulis Paragraf Persuasif Siswa Kelas X SMK Trisakti Baturaja. Jurnal Bindo Sastra, 2(1), 159. doi:10.32502/jbs.v2i1.923

Bomasati, A. (2019). Pengembangan LKPD Menulis Teks Persuasif Menggunakan Video untuk Siswa SMP KELAS VIII. Tesis, Magister Pendidikan Bahasa dan Sastra Indonesia, FKIP, Universitas Lampung, http://digilib.unila.ac.id/59430/3/TESIS\%20TANPA\%20BAB\%20PEMBAH ASAN.pdf

Daryanto, \& Dwicahyono, A. (2014). Pengembangan Perangkat Pembelajaran: Silabus, RPP, PHB, Bahan Ajar. Yogyakarta: Gava Media.

Fannie, R. D., dan Rohati. (2014). Pengembangan Lembar Kerja Siswa (LKS) Berbasis PEO (Predict, Observe, Explain) pada Materi Program Linier Kelas XII SMA. Jurnal Sainmatika, 8 (1), 96-109.

Haikal, A. D., Harjito, \& Umaya, N. M. (2018). Pemuatan Pendidikan Karakter dalam Pembelajaran Menulis Naskah Drama Satu Babak Berbasis Kontekstual sebagai Pengembangan Bahan Ajar Untuk Siswa SMP di Kota Semarang. Teks, 3(1), 1-2. doi:10.26877/teks.v3i1.2779

Hidayati, F. H., \& dkk. (2019). Hubungan Penguasaan Kalimat Efektif dan Kecerdasan Interpersonal dengan Keterampilan Menulis Teks Persuasi Siswa Kelas VIII SMPN 26 Kota Tangerang. Jurnal Membaca , 4(2), 8594. 
Karto, Suhartono, Susetyo, Noermanzah, Maisarah, I. (2019). The Differences Ability in Writing Descriptive Texts by Using Chain Writing and Conventional Methods. International Journal of Scientific \& Technology Research, 8(10), 2718.

Noermanzah, N. (2015). Peran Dosen Bahasa dan Sastra Indonesia dalam Mempertahankan Bahasa Indonesia sebagai Alat Pemersatu Negara Kesatuan Republik Indonesia pada Era Globalisasi. Dalam Prosiding Seminar Nasional Bulan Bahasa 2015. Unit Penerbitan FKIP Universitas Bengkulu, p. 277. http://repository.unib.ac.id/11133/

Noermanzah, N., Emzir, E., \& Lustyantie, N. (2017). Variety of Rhetorics in Political Speech President of the Republic of Indonesia Susilo Bambang Yudhoyono and Joko Widodo in Educational Field. Humanus, 16(2), 222223. doi:10.24036/humanus.v16i2.8103

Nugroho, A., Lazuardi, D. R., \& Murti, S. (2019). Pengembangan Bahan Ajar LKS Menulis Pantun Berbasis Kearifan Lokal Siswa Kelas VII SMP Xaverius Tugumulyo. KEMBARA: Jurnal Keilmuan Bahasa, Sastra, dan Pengajarannya, 5(1), 2. doi:10.22219/kembara.vol5.no1.1-12

Puspita, A. M. I., \& Purwo, S. (2019). Pengaruh Bahan Ajar Berbasis Literasi Dengan Pendekatan Kontekstual Terhadap Hasil Belajar Siswa Sekolah Dasar. Al-Aulad: Journal of Islamic Primary Education, 2(1), 2 doi:10.15575/al-aulad.v2i1.4426

Sukmadinata, N. S. (2012). Kurikulum dan Pembelajaran Kompetensi. Bandung: PT. Refika Aditama.

Tegeh, I., dkk. (2014). Model Penelitian Pengembangan. Yogyakarta: Graha Ilmu. 